\title{
Prevalence of Hepatitis B and C Virus Markers among Malaria-exposed Gold Miners in Brazilian Amazon
}

\author{
Francisco José Dutra Souto/ ${ }^{+}$, Cor Jésus Fernandes Fontes, \\ Ana Maria Coimbra Gaspar*
}

\begin{abstract}
Núcleo de Estudos de Doenças Infecciosas e Tropicais, Faculdade de Ciências Médicas, Universidade Federal de Mato Grosso, Caixa Postal 3241, 78048-790 Cuiabá, MT, Brasil *Departamento de Virologia, Instituto Oswaldo Cruz-Fiocruz, Rio de Janeiro, RJ, Brasil
\end{abstract}

Hepatitis $B$ and $C$ virus markers were assessed during a survey on malaria in gold mine camps in southern Brazilian Amazon in order to identify risk factors associated to these viral diseases. The study comprised 520 subjects, most of them were gold miners. Missing subjects totaled 49 (8.6\%). Among these 520, 82.9\% had HBV markers and $7.1 \%$ were HBsAg positive. Previous hospitalization, surgery, sexually transmitted diseases and incarceration were quite common among surveyed people, but there is no association between total HBV markers and these factors. On other hand, HBsAg was independently associated to history of sexually transmitted diseases and history of surgery after adjustment. The most frequent HBsAg subtypes identified, adw2 (59\%), predominates in populations of Northeast Brazil. The most surveyed people were immigrants coming from that area suggesting that immigrants carried $H B V$ themselves to the study area. Immunoblot (RIBA) confirmed-anti-HCV were found in $2.1 \%$. The only variable associated to anti-HCV in multivariate analysis was illicit intravenous drug. Lack of HCV infection in subjects with such a high $H B V$ markers prevalence reinforces the opinion that HCV is transmitted by restricted routes when compared to HBV. Furthermore, gold miners in Amazon may be considered as a risk group for HBV infection, but not for $\mathrm{HCV}$.

Key words: hepatitis B virus - hepatitis C virus - emigrations and immigration - epidemiology Brazilian Amazon

Malaria falciparum and hepatitis B virus (HBV) infections are quite common in Amazon Basin. Recent reports have shown that this situation also takes place in the southernmost part of the Brazilian Amazon, corresponding to the State of Mato Grosso (Andrade et al. 1995, Souto et al. 1998a, b). This vast sub-region became the target of a large influx of people from other Brazilian regions during the $70 \mathrm{~s}$ and $80 \mathrm{~s}$. The economic activities were formerly agriculture and cattle-raising, but goldmining has become an attractive trade to this low income population. Gold miners living and working in Amazon are exposed to body injuries, promiscuous sexual activity and tropical diseases. They frequently move to new gold prospecting places inside Amazon in as much as gold become scarce in prior areas (Santos et al. 1995). As a consequence gold miners are considered to facilitate malaria spread throughout the region (Andrade et

\footnotetext{
${ }^{+}$Corresponding author. Fax: $+55-65-615.7302$. E-mail: fsouto@nutecnet.com.br

Received 12 September 2000

Accepted 18 April 2001
}

al. 1995). Besides, a HBV markers prevalence study performed in a county of Mato Grosso suggested that gold miners may have taken a role in HBV spread as well (Souto et al. 1998b). However the routes involved in HBV transmission in this group remains unknown.

There are few reports on hepatitis $\mathrm{C}$ virus (HCV) prevalence in Amazon region. The prevalence of recombinant immunoblot (RIBA) confirmed-HCV antibodies ranges between $2.1 \%$ and $2.4 \%$ in studies from northernmost part of Mato Grosso (Souto et al. 1996, 1999). The only factor associated to HCV antibodies was previous use of parenteral illicit drugs (Souto et al. 1999).

A sero-epidemiologic study comprising inhabitants from mine camps located in Garimpo Satelite, county of Apiacas, north of the State of Mato Grosso, was performed in order to determine the hepatitis B and C markers prevalence and to identify factors associated to viral spread. Another aim was to study the HBV subtypes that are circulating among these subjects.

\section{MATERIALS AND METHODS}

This study was based on data collected during a survey on malaria carried out in Garimpo Satélite, a large area comprising 16 gold mine camps in 
Apiacas county. Before starting the field work, the Garimpo Satelite was censored by the researcher team in order to estimate the current number of inhabitants, regarding the mobility of this workers in Amazon and the necessity to bring up to date this information. All subject living in these camps were considered eligible to the study. The camp field was performed between March and June 1996.

The ethical and methodological aspects of this study were approved by the Federal University of Mato Grosso Research Ethical Committee. The objectives of the study were explained orally to all participants and consent of each participant was obtained. At the end of the study, individual blood tests results were given to each participant. Subjects identified as HBV or HCV carriers were directed to Hepatitis Care Program of Hospital Júlio Müller, Federal University of Mato Grosso, Cuiabá.

Each eligible individual was interviewed about demographic characteristics, previous malaria episodes and known risk factors associated with hepatitis transmission, including blood transfusion receipt, parenteral illicit drug use, dental treatment, number of sexual partners during lifetime, hospitalization, dental treatment, acupuncture and tattooing. Individuals born outside Mato Grosso were classified as immigrants and the time that each one lived in Amazon region was recorded.

Blood samples were drawn by venepuncture using vacuum tubes with EDTA. After preparing thin and thick blood smears, plasma were obtained and stored at $-20^{\circ} \mathrm{C}$ until tested at the Department of Virology, Instituto Oswaldo Cruz-Fiocruz, Rio de Janeiro. The samples were analyzed for HBV surface antigen and antibody (HBsAg and antiHBs, respectively), and total antibodies against $\mathrm{HBV}$ core antigen (anti-HBc), using enzyme immunoassays (EIA) from Organon TeknikaHepanostika, Boxtel, The Netherlands. HBsAg subtyping was also performed by EIA using monoclonal antibodies prepared at the Department of Virology (Niel et al. 1994). A subject was assumed to have been exposed to HBV if he or she had HBV markers (anti-HBc isolated or anti-HBc plus HBsAg or anti-HBs). IgG class antibodies against hepatitis D virus (anti-HDV) were also tested by EIA (Abbott, Chicago, IL, USA).

A third generation EIA was used to detect antiHCV antibodies (EIA, Abbott, Chicago). Positive samples were retested for confirmation with an immunoblot assay (RIBA) using immunodominant epitopes of core, E2/NS1, NS3, NS4, and NS5 antigens (Inno-LIA HCV Ab III, Innogenetics, Ghent, Belgium). These tests were performed at Department of Virology, Instituto Oswaldo Cruz. HCV infection was considered present in individuals with RIBA-confirmed anti-HCV.
Standard epidemiological methods of analysis of cross-sectional data were applied, including Student's t test, odds ratios, p values and $95 \%$ confidence intervals (95\% CI). Statistical significance was assessed at the 0.05 probability level in all analysis. Variables that showed differences between groups of at least a p value of 0.2 in univariate analysis were included in stepwise logistic regression models (Stata 5.0, Stata Corporation, Texas, USA) in order to identify those independently associated with exposure to HBV or $\mathrm{HCV}$.

\section{RESULTS}

Five hundred twenty individuals (91.4\%) of the 569 Garimpo Satelite's inhabitants were interviewed and bled. Most of missing eligible people were due to travel during the study period. Individuals refusing participation were only three. Among the study participants, $442(85 \%)$ were male and age ranged from 3 to 66 (mean $=32$ ). Most of them (79.6\%) were aged between 20 and 40 years. Immigrants were the majority of the community, especially coming from the Northeast Brazil ( $72.8 \%$ of the sample). These low income communities lived in bad hygienic conditions, in rustic and precarious cots located around the gold mines. The mean time living in this area was 7.5 years, ranging from 1 to 18 . Some behavioral characteristics of the sampled people appears in Table I.

Previous malaria episodes were admitted by $517(99.4 \%)$ of them and Plasmodium sp. were detected in 106 of them by thick blood smear ( $P$. falciparum, 56; $P$. vivax, 47; $P$. malarie, 3 ).

Among the 520 participants, 431 (82.9\%; CI95\%: 79.3\%; 86\%) people have been exposed to $\mathrm{HBV}$ and 37 (7.1\%; CI95\%: 5.1\%; 9.7\%) were HBsAg carriers. Only two (5.4\%) out of $37 \mathrm{HBsAg}$ carriers showed positivity to anti-HDV. The HBsAg subtypes were identified in 30 out of 37 . Small amount of serum samples preclude to subtyping HBsAg in other seven. Adw2 subtype were present in $22(59 \%)$, adw4 in $3(8.1 \%)$, ayw3 in $3(8.1 \%)$ and ayw2 in $2(5.4 \%)$.

No association were found between previous infection by HBV and all variables in univariate and multivariate analysis (Table I). When the HBsAg positivity was the outcome of the logistic model there was independent association to sexual transmitted disease (adjusted $\mathrm{OR}=3.9 ; 95 \% \mathrm{CI}=$ $1.3 ; 11.7 ; \mathrm{P}<0.05)$ and history of surgery (adjusted $\mathrm{OR}=5.0 ; 95 \% \mathrm{CI}=2.0 ; 12.9 ; \mathrm{P}<0.05)$ (Table II).

The EIA anti-HCV was present in $22(4.2 \%)$. The anti-HCV positivity was confirmed in 11 (2.1\%; CI95\%: $1.1 \%$; $3.9 \%$ ) by RIBA. The only variable associated to RIBA anti-HCV positivity in multivariate analysis was illicit intravenous drug 
use $($ adjusted $\mathrm{OR}=8.1 ; 95 \% \mathrm{CI}=1.1 ; 38.6 ; \mathrm{P}<0.05)$ (Table III).

Time living in Amazon was not associated to HBV or HCV markers.

\section{DISCUSSION}

A previous study on the prevalence of hepatitis B markers in south Amazon has suggested that gold miners represent a risk group for HBV infection and can facilitate its transmission as a consequence of their nomadic behavior (Souto et al. 1998b). That same study also showed that the prevalence of HBV markers among men aged between 20 and 40 ranged from $50 \%$ to $60 \%$. The present study, based on a population of gold miner camp of south Amazon, basically composed by

\section{TABLE I}

Prevalence of some behavioural and previous medical conditions of risk to hepatitis B virus (HBV) or hepatitis $\mathrm{C}$ virus (HCV) infection in whole surveyed, HBV exposed, HBV carriers and HCV exposed subjects

\begin{tabular}{|c|c|c|c|c|c|c|c|}
\hline Variable & $\begin{array}{c}\text { No. }(\%) \\
(\mathrm{HBV})\end{array}$ & $\begin{array}{c}\text { No. }(\%) \\
\text { HBV exposed }\end{array}$ & $P$ value & $\begin{array}{l}\text { No. }(\%) \\
(+) \text { HBsAg }\end{array}$ & $P$ value & $\begin{array}{c}\text { No. (\%) } \\
\text { Anti-HCV (+) }\end{array}$ & $\mathrm{P}$ value \\
\hline \multicolumn{8}{|c|}{ Hospitalization $^{a}$} \\
\hline Yes & $379(73.9)$ & $314(82.8)$ & \multirow[t]{2}{*}{$0.79^{b}$} & $24(6.3)$ & \multirow[t]{2}{*}{$0.76^{b}$} & $10(2.6)$ & \multirow[t]{2}{*}{$0.07^{c}$} \\
\hline No & $134(26.1)$ & $113(84.3)$ & & $11(8.2)$ & & $0(0)$ & \\
\hline \multicolumn{8}{|c|}{ Past surgery $^{a}$} \\
\hline Yes & $82(16)$ & $69(84.1)$ & \multirow{2}{*}{$0.93^{b}$} & $9(11)$ & \multirow{2}{*}{$0.16^{b}$} & $4(4.9)$ & \multirow[t]{2}{*}{$0.06^{c}$} \\
\hline No & $431(84)$ & $358(83.1)$ & & $26(6)$ & & $6(1.4)$ & \\
\hline \multicolumn{8}{|c|}{ Blood transfusion $^{a}$} \\
\hline Yes & $74(14.4)$ & $61(82.4)$ & \multirow[t]{2}{*}{$0.97^{b}$} & $7(9.5)$ & \multirow[t]{2}{*}{$0.47^{b}$} & $1(1.4)$ & \multirow[t]{2}{*}{$1.0^{c}$} \\
\hline No & $439(85.6)$ & $366(83.4)$ & & $28(6.4)$ & & $9(2.1)$ & \\
\hline \multicolumn{8}{|l|}{$\mathrm{STD}^{a, d}$} \\
\hline Yes & $268(59)$ & $229(85.4)$ & \multirow[t]{2}{*}{$0.28^{b}$} & $28(10.4)$ & \multirow[t]{2}{*}{$<0.01^{b}$} & $6(2.2)$ & \multirow[t]{2}{*}{$0.75^{c}$} \\
\hline No & $186(41)$ & $151(81.2)$ & & $5(2.7)$ & & $4(1.7)$ & \\
\hline \multicolumn{8}{|c|}{ Incarcerating } \\
\hline Yes & $66(12.9)$ & $53(80.3)$ & \multirow[t]{2}{*}{$0.6^{b}$} & $3(4.5)$ & \multirow[t]{2}{*}{$0.3^{c}$} & 0 & \multirow[t]{2}{*}{$0.37^{c}$} \\
\hline No & $447(87.1)$ & 374 (83.7) & & $32(7.2)$ & & $10(2.2)$ & \\
\hline \multicolumn{8}{|l|}{ IVDU $^{d}$} \\
\hline Yes & $17(3.3)$ & $16(94.1)$ & \multirow[t]{2}{*}{$0.37^{b}$} & $3(17.6)$ & \multirow[t]{2}{*}{$0.10^{c}$} & $2(11.8)$ & \multirow[t]{2}{*}{$0.04^{c}$} \\
\hline No & $496(96.7)$ & $411(82.9)$ & & $32(6.5)$ & & $8(1.6)$ & \\
\hline \multicolumn{8}{|c|}{$\begin{array}{l}\text { Male homosexual } \\
\text { experience }\end{array}$} \\
\hline Yes & $30(7.4)$ & $28(93.3)$ & \multirow[t]{2}{*}{$0.24^{b}$} & 0 & & 0 & \multirow[t]{2}{*}{$1.0^{c}$} \\
\hline No & $378(92.6)$ & $315(83.3)$ & & $33(8.7)$ & $<0.05^{c}$ & $7(1.9)$ & \\
\hline
\end{tabular}

a: regarding the entire lifetime; b: P value of Yates corrected chi-square; c: P value of two-tailed Fisher's exact test; d: STD: sexually transmitted disease; IVDU: intravenous drug users

\section{TABLE II}

Stepwise logistic regression model with variables associated in univariate analysis (outcome $=$ hepatitis B surface antigen)

\begin{tabular}{|c|c|c|c|c|c|}
\hline Variables $^{a}$ & $\begin{array}{c}\operatorname{HBs} \operatorname{Ag}(+) / \\
\text { no. examined }(\%)\end{array}$ & $\begin{array}{c}\text { Crude OR } \\
(95 \% \mathrm{CI})\end{array}$ & $\mathrm{P}$ & $\begin{array}{l}\text { Adjusted OR } \\
(95 \% \mathrm{CI})\end{array}$ & $\mathrm{P}$ \\
\hline \multicolumn{6}{|l|}{ Surgery } \\
\hline No & $26 / 431(6)$ & 1.0 (Reference) & & 1.0 (Reference) & \\
\hline Yes & $9 / 82(11)$ & $1.9(0.8 ; 4.5)$ & 0.16 & $5.0(2.0 ; 12.9)$ & $<0.01$ \\
\hline \multicolumn{6}{|c|}{ Parenteral illicit drug use } \\
\hline No & $33 / 496(6.5)$ & 1.0 (Reference) & & 1.0 (Reference) & \\
\hline Yes & $3 / 17(17.6)$ & $3.1(0.7 ; 12.5)$ & $0.1^{b}$ & $3.4(0.6 ; 18.6)$ & 0.16 \\
\hline \multicolumn{6}{|c|}{ Sexually transmitted disease } \\
\hline No & $5 / 186(2.7)$ & 1.0 (Reference) & & 1.0 (Reference) & \\
\hline Yes & $28 / 286(10.4)$ & $4.2(1.5 ; 12.8)$ & $<0.01$ & $3.9(1.3 ; 11.7)$ & $<0.05$ \\
\hline
\end{tabular}

$a$ : gender dropped out due to estimability; time of living in the study area and age removed due to no association with dependent variable $(\mathrm{p}>0.25) ; b$ : Fisher's exact test 


\section{TABLE III}

Stepwise logistic regression model with variables associated in univariate analysis (outcome $=$ RIBA confirmed-anti-HCV)

\begin{tabular}{|c|c|c|c|c|c|}
\hline Variables $^{a}$ & $\begin{array}{c}\text { Anti-HCV }(+) / \\
\text { Total }(\%)\end{array}$ & $\begin{array}{c}\text { Crude OR } \\
(95 \% \mathrm{CI})\end{array}$ & $\mathrm{P}$ & $\begin{array}{l}\text { Adjusted OR } \\
(95 \% \mathrm{CI})\end{array}$ & $\mathrm{P}$ \\
\hline \multicolumn{6}{|l|}{ Age (years) } \\
\hline $3-25$ & $1 / 95(1.0)$ & & & 1.0 (Reference) & \\
\hline $26-30$ & $2 / 140(1.4)$ & & & $2.2(0.2 ; 28.6)$ & 0.5 \\
\hline $31-40$ & $5 / 193(2.6)$ & & & $4.4(0.4 ; 47.2)$ & 0.2 \\
\hline $41-66$ & $3 / 85(3.5)$ & & $0.18^{a}$ & $4.6(0.3 ; 69.1)$ & 0.3 \\
\hline \multicolumn{6}{|c|}{ Previous IVD use } \\
\hline No & $8 / 496$ (1.6) & 1.0 (Reference) & & 1.0 (Reference) & \\
\hline Yes & 2/17 (11.8) & $8.1(1.1 ; 38.6)$ & $<0.05$ & $10.6(1.6 ; 69.1)$ & 0.01 \\
\hline
\end{tabular}

$a$ : IVD: intravenous drug use; $\mathrm{P}$ value of OR for trend with age less than 26 as reference; hospitalization dropped out due to estimability.

males aged between 20 and 40, showed a quite high prevalence of HBV markers $(82.9 \%)$. Such a high prevalence of HBV markers likely precluded a statistical association between HBV exposure and analyzed independent variables, such as blood transfusion, surgical procedures, hospitalization, intravenous illicit drug use, history of incarceration, sexually transmitted disease. However, when analyzed alone $\mathrm{HBs} \mathrm{Ag}$ positivity was associated to previous surgery and sexual transmitted diseases. Sexual activity is quite known as an important route for HBV spread. Association between HBsAg positivity and previous surgery may represent use of inadequately sterilized syringes and nosocomial treatments.

The adw2 HBV subtype has been shown to predominate in populations of Northeast Brazilian region (Gaspar \& Yoshida 1988). This was original area of the most surveyed people, suggesting that immigrants from this Brazilian region carried the HBV themselves from there to the study area. However, Northeast Brazil HBV prevalence is poorly known (Souto 1999). Since there is no association between HBV markers and time living in south Amazon, we can not assert where and when these subjects kept infected by HBV.

Despite of the high prevalence of HBV-HDV coinfection in western Amazon, the number of coinfected individuals in the present study points out that the Delta agent has not been largely introduced in the southern Brazilian Amazon so far, in agreement with previous studies (Souto et al. 1998a,b).

The prevalence of HCV infection was low-tomoderate among these subjects, even though they were highly exposed to injuries, promiscuous sexual activity and surgical procedures. The only classical risk factor associated to the presence of anti-HCV in this survey was history of parenteral drug use. Such few cases of HCV infection in subjects with these characteristics reinforce the opinion that $\mathrm{HCV}$ is poorly transmitted by routes other than sharing syringes and needles or by blood transfusion.

In the present study, half of the anti-HCV positive by EIA were not-confirmed. Aceti et al. (1990) studying $\mathrm{HCV}$ infection in a Cameroon malarigenous area showed similar results, supposing that the stimulation of a policlonal antibodies production from recurrent malaria infection could also produce false-positive anti-HCV EIA tests.

Finally, these data reinforce that gold mine workers in the Amazon may be considered as a risk group for $\mathrm{HBV}$ infection, but not for $\mathrm{HCV}$. Ever since these workers are constantly moving inside Amazon and exposing themselves to sexual and parenteral transmitted diseases, a surveillance system on HDV superinfection should be developed, in as much as HDV can deteriorate the prognosis of $\mathrm{HBV}$ infection and both viruses share the same transmission routes.

\section{REFERENCES}

Aceti A, Taliani G, De Bac C, Sebastiani A 1990. AntiHCV false positivity in malaria. Lancet 336 : 14421443.

Andrade AL, Martelli CM, Oliveira RM, Arias JR, Zicker F, Pang L 1995. High prevalence of asymptomatic malaria in gold mining areas in Brazil. Clin Infect Dis 20: 475.

Gaspar AMC, Yoshida CFT 1988. Geographic distribution of HBsAg subtypes in Brazil. Mem Inst Oswaldo Cruz 82: 105-111.

Niel C, Moraes MTB, Gaspar AMC, Yoshida CFT, Gomes AS 1994. Genetic diversity of hepatitis B virus strains isolated in Rio de Janeiro, Brazil. J Med Virol 44: 180-186.

Santos EO, Loreiro ECB, Jesus IM, Brabo E, Silva RSU, Soares MCP, Câmara VM, Souza MRS, Branches F 
1995. Diagnóstico das condições de uma comunidade garimpeira em uma região do Rio Tapajós, Itaituba, Pará, Brasil. Cad Saúde Públ 11: 212-225.

Souto FJD 1999. Distribuição da hepatite B no Brasil: atualização do mapa epidemiológico e proposições para seu controle. Gastroenterol Endosc Digest 18: 143-150.

Souto FJD, Fontes CJF, Gaspar AMC 1998b. Outbreak of hepatitis B virus in recent arrivals to the Brazilian Amazon. J Med Virol 56: 4-9.

Souto FJD, Fontes CJF, Gaspar AMC, Lyra LGC 1998a. Hepatitis B virus in immigrants to the southern Bra- zilian Amazon. Trans R Soc Trop Med Hyg 92: 282284.

Souto FJD, Fontes CJF, Gaspar AM, Paraná R, Lyra LGC 1996. Concomitant high prevalence of hepatitis $\mathrm{C}$ virus antibodies and hepatitis $\mathrm{B}$ virus markers in a small village of the Amazon region, Mato Grosso State, Brazil. Rev Inst Med Trop São Paulo 38: 221224.

Souto FJD, Fontes CJF, Martelli CMT, Turchi MD, Martins RMB, Andrade ALSS 1999. Hepatitis C virus prevalence among an immigrant community to the Southern Amazon, Brazil. Mem Inst Oswaldo Cruz 94: 719-726. 